KInga KrZESIwO

Uniwersytet Pedagogiczny w Krakowie, Polska - Pedagogical University of Cracow, Poland

\title{
Społeczne i gospodarcze aspekty rozwoju turystyki narciarskiej
}

\author{
Social and Economic Aspects of Development of Ski Tourism
}

\begin{abstract}
Streszczenie: Rozwój ośrodków narciarskich jest najważniejszym czynnikiem rozwoju społeczno-gospodarczego niektórych krajów i regionów górskich. Przyczynia się do wzrostu demograficznego oraz poprawy jakości usług i infrastruktury w miejscowościach górskich, jest ważnym źródłem zatrudnienia i dochodów mieszkańców, a także kreuje tzw. psychologiczną stabilność osób zamieszkujących te tereny. Celem niniejszego artykułu jest ukazanie, na podstawie danych uzyskanych z Banku Danych Lokalnych GUS, wpływu rozwoju ośrodków narciarskich na rozwój społeczno-gospodarczy 16 gmin, na terenie których leżą największe stacje narciarskie polskich Karpat. Pod względem społecznym i gospodarczym badane gminy są znacznie zróżnicowane. Przejawia się to m.in. w saldzie migracji, poziomie bezrobocia i przedsiębiorczości, a także w strukturze podmiotów gospodarczych. W zdecydowanie najkorzystniejszej sytuacji znajdują się te gminy, w których turystyka narciarska odgrywa istotną rolę w strukturze ich funkcji turystycznej. Są to przede wszystkim gminy położone w Beskidzie Śląskim i na Podhalu. Charakteryzują się one przeważnie dodatnim saldem migracji, niższym poziomem bezrobocia niż średni poziom dla Polski i wyższym od średniego poziomem przedsiębiorczości. Odwrotne cechy wykazują natomiast gminy słabiej zagospodarowane dla narciarstwa, leżące w Beskidzie Żywieckim, Beskidzie Sądeckim, Pieninach i Bieszczadach.
\end{abstract}

\begin{abstract}
The development of ski resorts is the most important factor of socio-economic development of some countries and mountain regions. It contributes to the demographic growth and improves the quality of services and the infrastructure in the mountain locations. It is also an important source of employment and income of inhabitants as well as it creates the so-called "psychological stability" of people living in these areas. The aim of this article is to show, based on data obtained from the Local Data Bank of the Central Statistical Office, the impact of development of ski resorts on the socio-economic development of 16 municipalities, where the largest ski stations of the Polish Carpathians are located. The investigated municipalities differ significantly in terms of social and economic situation. This is reflected, among others, in the balance of migration, the level of unemployment, the level of entrepreneurship as well as the structure of business entities. Definitely those municipalities where ski tourism plays an essential role in the structure of their tourism function are in the best situation. There are mainly municipalities located in the Silesian Beskid and in the Podhale region. They are mostly characterized by positive migration balance, lower than the average level of unemployment for Poland and higher than the average level of entrepreneurship. The reverse features have the municipalities which are less developed for ski tourism, located in the Żywiecki Beskid, the Sądecki Beskid, the Pieniny Mountains and the Bieszczady Mountains.
\end{abstract}


Słowa kluczowe: Karpaty Polskie; ośrodki narciarskie; rozwój społeczno-gospodarczy; turystyka narciarska

Keywords: Polish Carpathians; ski resorts; ski tourism; socio-economic development

Otrzymano: 18 października 2015

Received: 18 October 2015

Zaakceptowano: 29 marca 2016

Accepted: 29 March 2016

\section{Sugerowana cytacja/Suggested citation:}

Krzesiwo, K. (2016). Społeczne i gospodarcze aspekty rozwoju turystyki narciarskiej. Przedsiębiorczość - Edukacja, 12, 233-244.

\section{Wstęp}

Od początku XXI w. nastąpił znaczący wzrost uczestnictwa Polaków w turystyce narciarskiej. Z badań przeprowadzonych przez Instytut Pentor wynika, że w sezonie zimowym 2003/2004 ok. 2\% mieszkańców naszego kraju deklarowało uprawianie narciarstwa, a w sezonie 2008/2009 ok. 14\%, tj. ok. 5 mln osób. Wzrost ruchu turystycznego w polskich stacjach narciarskich spowodował nasilenie się procesu transformacji jakościowej istniejących urządzeń przeznaczonych do transportu narciarzy po stokach oraz tworzenia nowych urządzeń tego typu (Krzesiwo, 2014). Obserwuje się duże zainteresowanie rozwojem infrastruktury narciarskiej, szczególnie dla narciarstwa zjazdowego, zarówno ze strony potencjalnych inwestorów, jak i władz samorządowych. Wynika to przede wszystkim z komercjalizacji tej formy turystyki oraz oczekiwanych korzyści ekonomicznych. Masowy charakter turystyki narciarskiej i wielkość związanych z nią obrotów finansowych powodują, że miejscowości górskie upatrują w niej wzrostu zatrudnienia i dochodów miejscowej ludności oraz źródła rozwoju lokalnej przedsiębiorczości. W niektórych krajach lub regionach ta forma turystyki jest najważniejszym czynnikiem rozwoju gospodarczego. Przyczynia się do wzrostu demograficznego oraz poprawy jakości usług i infrastruktury w miejscowościach górskich, jest ważnym źródłem zatrudnienia i dochodów mieszkańców, a także kreuje tzw. psychologiczną stabilność osób zamieszkujących te tereny (Barbier, 1978, 1993; Buckley, Pickering, Warnker, 2000; Christopoulou, Papastavrou, 1997; Čuka, Gregorová, 2011; Greif, 1988; Havrlant, 2011; Knafau, 1979; Krzesiwo, 2014; Kurek, 2004; Lasanta, Laguna, Vincente-Serrano, 2007; Lindberg, Andersson, Dellaert, 2001; Mika, 2014; Orens, Seidl, Weiler, 2006; Snowdon, Slee, Farr, 2000; Zimmermann, 1995).

Celem artykułu jest ukazanie wpływu turystyki narciarskiej na rozwój społeczno-gospodarczy 16 gmin, na terenie których leżą największe stacje narciarskie polskich Karpat.

Zakres przestrzenny badań obejmuje 19 miejscowości o najlepiej rozwiniętej infrastrukturze narciarskiej. Jako wartość progową decydującą o przyjęciu miejscowości do badań przyjęto łączną zdolność przewozową urządzeń wyciągowych w sezonie 2014/2015 większą lub równą 5000 os./godz. Są to takie miejscowości, jak: Brenna, Istebna, Szczyrk, Ustroń i Wisła w Beskidzie Śląskim, Zwardoń położony w Beskidzie Śląskim i Żywieckim, Korbielów i Zawoja w Beskidzie Żywieckim, Kluszkowce w Pieninach, Krynica-Zdrój i Wierchomla w Beskidzie Sądeckim, Ustrzyki Dolne w Bieszczadach, Białka Tatrzańska, Bukowina Tatrzańska, Czarna Góra, Jurgów, Małe Ciche, Witów na Podhalu oraz Zakopane, którego tereny narciarskie zlokalizowane są w Tatrach i na Podhalu (ryc. 1). 
Obszar badań położony jest na terenie 3 województw: śląskiego, małopolskiego i podkarpackiego, należy do 8 powiatów: cieszyńskiego, bielskiego, żywieckiego, suskiego, tatrzańskiego, nowotarskiego, nowosądeckiego i bieszczadzkiego, oraz wchodzi w skład 16 gmin: Brenna, Ustroń, Wisła, Istebna, Szczyrk, Rajcza, Jeleśnia, Zawoja, Kościelisko, Zakopane, Poronin, Bukowina Tatrzańska, Czorsztyn, Piwniczna-Zdrój, Krynica-Zdrój i Ustrzyki Dolne (tab. 1).

Ryc. 1. Lokalizacja badanych stacji narciarskich w polskich Karpatach

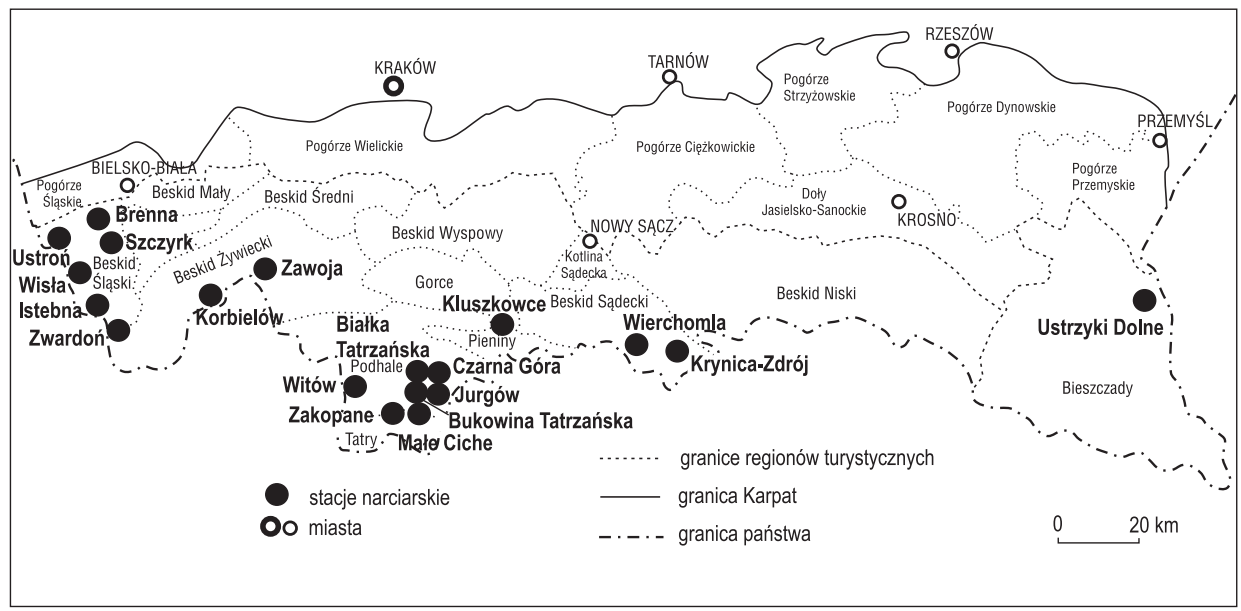

Źródło: opracowanie własne

Tab. 1. Powiązania badanych stacji narciarskich z podziałem administracyjnym

\begin{tabular}{|c|c|c|c|}
\hline Województwo & Powiat & Gmina & Stacja narciarska \\
\hline \multirow[t]{7}{*}{ śląskie } & bielski & Szczyrk & Szczyrk \\
\hline & \multirow[t]{4}{*}{ cieszyński } & Brenna & Brenna \\
\hline & & Istebna & Istebna \\
\hline & & Ustroń & Ustroń \\
\hline & & Wisła & Wisła \\
\hline & \multirow[t]{2}{*}{ żywiecki } & Jeleśnia & Korbielów \\
\hline & & Rajcza & Zwardoń \\
\hline \multirow[t]{11}{*}{ małopolskie } & \multirow[t]{2}{*}{ nowosądecki } & Krynica-Zdrój & Krynica-Zdrój \\
\hline & & Piwniczna-Zdrój & Wierchomla \\
\hline & nowotarski & Czorsztyn & Kluszkowce \\
\hline & \begin{tabular}{|l|} 
suski \\
\end{tabular} & Zawoja & Zawoja \\
\hline & \multirow[t]{7}{*}{ tatrzański } & \multirow[t]{4}{*}{ Bukowina Tatrzańska } & Białka Tatrzańska \\
\hline & & & Bukowina Tatrzańska \\
\hline & & & Czarna Góra \\
\hline & & & Jurgów \\
\hline & & Kościelisko & Witów \\
\hline & & Poronin & Małe Ciche \\
\hline & & Zakopane & Zakopane \\
\hline podkarpackie & bieszczadzki & Ustrzyki Dolne & Ustrzyki Dolne \\
\hline
\end{tabular}

Źródło: opracowanie własne 
Cel pracy został osiągnięty dzięki wykorzystaniu kilku metod badawczych. Pierwszy etap badań, przeprowadzony w latach 2010-2012, obejmował wywiady z gestorami bazy narciarskiej, przedstawicielami gmin oraz osobami zaangażowanymi w rozwój narciarstwa na temat rozwoju infrastruktury narciarskiej w miejscowościach wyposażonych w wyciągi narciarskie i koleje linowe w polskich Karpatach. W drugim etapie dokonano inwentaryzacji infrastruktury narciarskiej w sezonie zimowym 2014/2015 w polskiej części Karpat. Po wytypowaniu stacji narciarskich do badań nastąpił trzeci etap realizacji pracy, który polegał na uzyskaniu z Banku Danych Lokalnych GUS danych z 2004 r. i 2014 r. dotyczących sytuacji społecznej i gospodarczej gmin, na terenie których zlokalizowane są największe stacje narciarskie polskich Karpat oraz na opracowaniu materiałów źródłowych.

\section{Rozwój turystyki narciarskiej w polskich Karpatach}

Tradycje uprawiania narciarstwa w Polsce, jako jednej z form spędzania czasu wolnego, sięgają ostatniej dekady XIX w. i związane są z popularyzacją zimowych wędrówek górskich z przypiętymi do nóg nartami (Barabasz, 1914; Paryski, Paryska, 1994; Szatkowski, 1994, 2011; Ziemba, 1957). Uprawianie turystyki narciarskiej stało się modne w okresie międzywojennym. W tym czasie głównymi bazami dla narciarzy były: Zakopane, Wisła, Zwardoń, Szczyrk, Korbielów, Sławsko i Worochta (Krzesiwo, 2014). Przełomowym momentem w historii polskiego narciarstwa, który zapoczątkował rozwój narciarstwa zjazdowego w naszym kraju, było uruchomienie w 1936 r. Kolei Linowej na Kasprowy Wierch w Zakopanem (Baran, 2010). Do wybuchu II wojny światowej w polskich Karpatach działało 5 urządzeń wyciągowych, w tym 3 w Zakopanem i po jednym w Krynicy oraz w Sławsku.

Po okresie wojennym, w latach 50. XX w., koleje linowe i wyciągi narciarskie zaczęto lokować w miejscowościach $\mathrm{z}$ tradycjami narciarskimi oraz dobrymi warunkami zagospodarowania turystycznego. Dynamiczny rozwój infrastruktury narciarskiej w polskiej części Karpat następował od początku lat 70. XX w. W latach 1970-1989 oddano do użytku ponad 240 urządzeń przeznaczonych do transportu narciarzy po stokach. W zachodniej części Beskidów Zachodnich baza narciarska była tworzona głównie za sprawą zakładów przemysłowych, które lokowały wyciągi i trasy narciarskie przy własnych domach wczasowych. Na pozostałym obszarze infrastruktura narciarska należała przede wszystkim do przedsiębiorstw turystycznych będących własnością Skarbu Państwa. W 1989 r. spośród 85 miejscowości wyposażonych w infrastrukturę narciarską największą rangę miały Zakopane i Szczyrk, w których działało po 30 urządzeń wyciągowych. Wysokim stopniem rozwoju charakteryzowały się także Bukowina Tatrzańska, Wisła i Korbielów, które miały odpowiednio po 21, 20 i 12 wyciągów narciarskich. Uzupełnieniem powyższych stacji była grupa 6 miejscowości posiadających od 5 do 9 urządzeń przeznaczonych do transportu narciarzy po stokach. Były to: Brenna, Żabnica, Ustroń, Krynica-Zdrój, Piwniczna-Zdrój i Zwardoń (Krzesiwo, 2014).

Po 1989 r. nastąpiły zmiany w zagospodarowaniu narciarskim na obszarze polskich Karpat. Były one ściśle związane z przebiegiem procesu transformacji systemu społeczno-gospodarczego państwa. Bezpośrednim jego efektem była prywatyzacja infrastruktury narciarskiej należącej do zakładów przemysłowych i innych jednostek stanowiących mienie Skarbu Państwa. W pierwszym etapie zmian częstym zjawiskiem było oddawanie ośrodków narciarskich lub pojedynczych wyciągów w dzierżawę. Dzierżawcami stawały się przeważnie osoby lub spółki miejscowe prowadzące działalność gospodarczą. Infrastruktura narciarska zaczęła zatem funkcjonować w układzie lokalnym (Mika, 2004). Proces prywatyzacji oraz rozwój 
działalności gospodarczej w sektorze turystycznym doprowadziły do zmiany struktury własnościowej infrastruktury narciarskiej w 2012 r. w porównaniu z 1989 r. Końcem 2012 r. aż 86,1\% urządzeń wyciągowych znajdowała się w rękach sektora prywatnego, podczas gdy w 1989 r. jedynie 17,1\%. Znaczne ograniczenie roli turystyki socjalnej stworzyło także konieczność dostosowania oferty stacji narciarskich do aktualnych potrzeb ruchu turystycznego m.in. przez modernizację infrastruktury narciarskiej, rozbudowę istniejących i budowę nowych ośrodków narciarskich, stosowanie urządzeń do naśnieżania tras narciarskich czy wzrost liczby obiektów gastronomicznych i świadczących usługi dla narciarzy (Krzesiwo, 2014).

W ostatniej dekadzie XX w. powstały jedne z największych, współcześnie funkcjonujących w Polsce, ośrodków narciarskich, takich jak: Jaworzyna Krynicka w Krynicy-Zdroju i Dwie Doliny Muszyna-Wierchomla w Wierchomli, a także Czorsztyn-ski w Kluszkowcach. Na przełomie XX i XXI w. najważniejszymi stacjami narciarskimi nadal były Zakopane i Szczyrk. Miasta te dysponowały najlepszą bazą dla narciarstwa zjazdowego. W Zakopanem działało 50 urządzeń wyciągowych, a w Szczyrku 34. Wysoką rangę miały także: Wisła, Zwardoń, Korbielów, Bukowina Tatrzańska, Piwniczna-Zdrój i Krynica-Zdrój. Miejscowości te miały od 11 do 26 urządzeń przeznaczonych do transportu narciarzy po stokach. Ważne miejsce wśród stacji narciarskich zlokalizowanych w polskich Karpatach zajmowały również: Brenna, Ustroń, Zawoja, Białka Tatrzańska, i Tylicz. Pod koniec lat 90. XX w. znajdowało się w nich od 8 do 10 wyciągów narciarskich i kolei linowych (Krzesiwo, 2014).

W pierwszej dekadzie XXI w., za sprawą zwiększającej się liczby uczestników narciarskiego ruchu turystycznego w Polsce, nasilił się proces transformacji istniejących urządzeń oraz tworzenia nowej infrastruktury narciarskiej. Modernizacji podlegały przede wszystkim wyciągi orczykowe i talerzykowe, które w wielu wypadkach zastępowano krzesełkowymi kolejami linowymi. Tego typu zabiegi modernizacyjne prowadzono m.in. w ośrodkach narciarskich Ustronia, Wisły, Istebnej, Zwardonia, Krynicy-Zdrój czy Zakopanego. W tym czasie powstało też wiele nowych ośrodków narciarskich, szczególnie w regionie podhalańskim. Większość z nich była tworzona przez lokalne grupy przedsiębiorców. Pierwszym tego typu ośrodkiem, powstałym w 2001 r., była Kotelnica Białczańska w Białce Tatrzańskiej. Wzorując się na inicjatywie podjętej przez białczańską społeczność, mieszkańcy innych podhalańskich wsi również zaczęli zakładać spółki i tworzyć ośrodki narciarskie. Przykładem nowych ośrodków narciarskich są m.in.: Małe Ciche (2004 r.) w Małem Cichem, Harenda (2004 r.) w Zakopanem, Witów-ski (2006 r.) w Witowie, Koziniec (2006 r.) i Grapa-Litwinka (2010 r.) w Czarnej Górze, Jurgów-ski (2007 r.) w Jurgowie, Rusiń-ski (2009 r.) w Bukowinie Tatrzańskiej czy Suche (2012 r.) w Suchem koło Poronina. Zaletą nowo powstałych ośrodków jest ich nowoczesne wyposażenie, m.in.: w koleje linowe, snowparki, regionalne karczmy i bezpłatne parkingi (Krzesiwo, 2014).

Od początku XXI w. rozwój jakościowy infrastruktury narciarskiej następuje szybciej niż rozwój ilościowy. Świadczy o tym m.in. fakt, że w okresie między 1999 a 2012 r. liczba urządzeń wyciągowych na obszarze polskich Karpat wzrosła o 25,6\%, a ich zdolność przewozowa aż o $66,7 \%$. Wraz z rozwojem tego typu infrastruktury zmieniła się także ranga niektórych stacji narciarskich. Zdecydowanie wzrosła rola Białki Tatrzańskiej, Krynicy-Zdroju i Wisły. W każdej z tych miejscowości w pierwszej dekadzie XXI w. powstało po kilka kolei linowych i kilkanaście wyciągów narciarskich (Krzesiwo, 2014). Pojawiły się również nowe stacje narciarskie, takie jak: Czarna Góra, Jurgów, Małe Ciche i Witów na Podhalu, Kluszkowce w Pieninach, Wierchomla w Beskidzie Sądeckim i Ustrzyki Dolne w Bieszczadach. 
W XXI w., głównie w Piwnicznej-Zdroju, Szczyrku i Zakopanem, nasiliły się kwestie sporne pomiędzy gestorami wyciągów narciarskich a właścicielami gruntów, po których przebiegały trasy. Wpłynęły one niekorzystnie na postrzeganie przez narciarzy tych stacji narciarskich, co w efekcie przyczyniło się do mniejszego popytu turystycznego w sezonie zimowym, a także likwidacji niektórych urządzeń wyciągowych i tras zjazdowych.

Z przeprowadzonej w sezonie zimowym 2014/2015 inwentaryzacji wynika, że pierwszoplanowe miejsce wśród stacji narciarskich w Karpatach polskich zajmują: Zakopane, Wisła, Białka Tatrzańska i Krynica-Zdrój. Każda z nich jest wyposażona w kilkadziesiąt wyciągów narciarskich i kolei linowych o łącznej zdolności przewozowej przekraczającej 25 tys. os./godz. (tab. 2). Wysokim poziomem rozwoju bazy narciarskiej dysponują także: Szczyrk, Bukowina Tatrzańska, Korbielów i Wierchomla. W tych stacjach narciarskich znajduje się od kilkunastu do kilkudziesięciu urządzeń wyciągowych, a ich łączna zdolność przewozowa wynosi od 10 tys. do 20 tys. os./godz. Uzupełnieniem powyższych stacji jest grupa 11 miejscowości mających po kilka lub kilkanaście urządzeń przeznaczonych do transportu narciarzy po stokach. Ich łączna zdolność przewozowa mieści się w przedziale od 5 tys. do 10 tys. os./godz. Są to: Brenna, Ustroń, Istebna, Zwardoń, Zawoja, Witów, Małe Ciche, Czarna Góra, Jurgów, Kluszkowce i Ustrzyki Dolne.

Tab. 2. Infrastruktura dla narciarstwa zjazdowego w badanych stacjach narciarskich polskich Karpat w sezonie 2014/2015

\begin{tabular}{|l|c|c|c|}
\hline \multirow{2}{*}{ Miejscowość } & \multicolumn{2}{|c|}{ Liczba urządzeń wyciągowych } & $\begin{array}{c}\text { Zdolność przewozowa } \\
\text { urządzeń wyciągowych } \\
\text { [osób/godz.] }\end{array}$ \\
\cline { 2 - 3 } & ogółem & $\begin{array}{c}\text { w tym kolei } \\
\text { linowych }\end{array}$ & 28395 \\
\hline Białka Tatrzańska & 23 & 8 & 5550 \\
\hline Brenna & 10 & 0 & 15964 \\
\hline Bukowina Tatrzańska & 21 & 3 & 7100 \\
\hline Czarna Góra & 7 & 2 & 8987 \\
\hline Istebna & 8 & 2 & 7700 \\
\hline Jurgów & 6 & 2 & 5800 \\
\hline Kluszkowce & 6 & 2 & 14945 \\
\hline Korbielów & 18 & 4 & 27059 \\
\hline Krynica-Zdrój & 29 & 7 & 7850 \\
\hline Małe Ciche & 7 & 2 & 18240 \\
\hline Szczyrk & 30 & 2 & 8908 \\
\hline Ustroń & 13 & 3 & 11060 \\
\hline Ustrzyki Dolne & 8 & 1 & 28793 \\
\hline Wierchomla* & 12 & 2 & 5100 \\
\hline Wisła & 39 & 5 & 29965 \\
\hline Witów & 8 & 1 & 5924 \\
\hline Zakopane & 44 & 8 & 8620 \\
\hline Zawoja & 9 & 1 & \\
\hline Zwardoń & 16 & 1 & \\
\hline
\end{tabular}

*W badaniach uwzględniono także urządzenia wyciągowe położone po stronie Szczawnika, ponieważ Ośrodek Narciarski Dwie Doliny Muszyna Wierchomla funkcjonuje jako kompleks narciarski.

Źródło: opracowanie własne na podstawie badań terenowych 
Charakterystyka społeczna i gospodarcza badanych gmin

Na możliwości rozwoju turystyki w dużej mierze ma wpływ sytuacja demograficzna. Miejscowości z dużą liczbą mieszkańców stwarzają dogodne warunki do obsługi ruchu turystycznego, gdyż dysponują zasobami siły roboczej, potencjalnie dużą liczbą obiektów noclegowych oraz dobrym wyposażeniem w infrastrukturę społeczną i techniczną. Charakteryzują się także zazwyczaj dobrą dostępnością komunikacyjną.

W 2014 r. gminy objęte badaniami zamieszkiwało łącznie 187 tys. osób, z czego w stacjach narciarskich - 114 tys. osób (61,0\% badanej populacji). Spośród badanych stacji najwięcej mieszkańców liczą miasta: Zakopane (27,5 tys.), Ustroń (16,1 tys.), Wisła (11,2 tys.) i Krynica-Zdrój (11,0 tys.). Wśród miejscowości o charakterze wiejskim największą liczbą ludności odznaczają się: Zawoja (6,5 tys.), Brenna (6,1 tys.) i Istebna (5,1 tys.). Z kolei najmniej osób mieszka w sołectwach: Małe Ciche (486), Wierchomla (764 osoby), na które składają się dwie wsie - Wierchomla Wielka (674 osoby) i Wierchomla Mała (90 osób), Zwardoń (910 osób) i Jurgów (926 osób).

W latach 2004-2014 ponad 60\% badanych gmin cechowało się wzrostem ogólnej liczby ludności (tab. 3). Największy przyrost mieszkańców odnotowano w gminach Brenna, Bukowina Tatrzańska i Poronin, gdzie w ciągu ostatnich 10 lat liczba osób zamieszkujących te gminy zwiększyła się odpowiednio o 1048, 872 i 852. W ujęciu procentowym zjawisko to najwyraźniej zarysowało się w gminach Brenna (wzrost o 10,5\%), Kościelisko (8,5\%) i Poronin (8,1\%). Z kolei największy ubytek ludności nastąpił w Krynicy-Zdrój i Ustrzykach Dolnych. W ostatnim dziesięcioleciu liczba ludności w tych miastach zmniejszyła się odpowiednio o 637 i 351 osób.

Tab. 3. Struktura ludnościowa gmin, w skład których wchodzą badane stacje narciarskie

\begin{tabular}{|l|c|c|c|c|}
\hline \multicolumn{1}{|c|}{ Gmina } & $\begin{array}{c}\text { Liczba } \\
\text { ludności }\end{array}$ & $\begin{array}{c}\text { Zmiana liczby } \\
\text { ludności w latach } \\
\mathbf{2 0 0 4 - 2 0 1 4}\end{array}$ & $\begin{array}{c}\text { Przyrost } \\
\text { naturalny } \\
(\mathbf{\% o})\end{array}$ & $\begin{array}{c}\text { Saldo } \\
\text { migracji } \\
(\%)\end{array}$ \\
\hline Brenna & 11064 & 1048 & 0,4 & 8,0 \\
\hline Bukowina Tatrzańska & 13138 & 872 & 4,6 & $-0,3$ \\
\hline Czorsztyn & 7573 & 427 & 4,5 & 0,5 \\
\hline Istebna & 11935 & 654 & 5,3 & $-2,0$ \\
\hline Jeleśnia & 13426 & -91 & $-2,2$ & $-2,5$ \\
\hline Kościelisko & 8639 & 678 & 1,3 & 1,4 \\
\hline Krynica-Zdrój (miasto) & 10992 & -637 & $-4,3$ & $-9,0$ \\
\hline Piwniczna-Zdrój & 10667 & 252 & 1,3 & $-3,9$ \\
\hline Poronin & 11422 & 852 & 5,6 & b.d. ${ }^{*}$ \\
\hline Rajcza & 9025 & -19 & $-3,2$ & $-2,8$ \\
\hline Szczyrk & 5799 & 146 & $-0,9$ & 2,3 \\
\hline Ustroń & 16073 & 783 & $-2,2$ & 1,8 \\
\hline Ustrzyki Dolne (miasto) & 9383 & -351 & 0,1 & $-2,6$ \\
\hline Wisła & 11198 & -89 & 0,5 & $-1,9$ \\
\hline Zakopane & 27556 & 4 & $-2,7$ & $-2,2$ \\
\hline Zawoja & 9072 & 235 & 0,2 & $-0,7$ \\
\hline
\end{tabular}

${ }^{\star}$ Brak danych.

Źródło: opracowanie własne na podstawie danych z Banku Danych Lokalnych GUS (2014) 
W 2014 r. najwyższe dodatnie saldo migracji notowały gminy położone w Beskidzie Śląskim. W Brennej wskaźnik ten kształtował się na poziomie 8\%o, w Szczyrku 2,3\%, a w Ustroniu 1,8\%o (tab. 3). Z kolei najniższymi wartościami tego wskaźnika charakteryzowały się głównie gminy Beskidu Żywieckiego, Beskidu Sądeckiego i Bieszczad. Największe ujemne saldo migracji zanotowano w Krynicy-Zdroju (-9,0\%) i gminie Piwniczna-Zdrój (-3,9\%) oraz w gminach Rajcza $(-2,8 \%$ ), Jeleśnia $(-2,5 \%)$ i w Ustrzykach Dolnych $(-2,6 \%$ )

W zakresie przyrostu naturalnego badane gminy odzwierciedlają tendencje ogólnopolskie. W 10 gminach wartości tego wskaźnika są dodatnie, a w 6 ujemne (tab. 3). Największy przyrost naturalny cechuje gminy wiejskie: Poronin (5,6\%o), Istebną (5,3\%o), Bukowinę Tatrzańską $(4,6 \%$ ) i Czorsztyn $(4,5 \%)$, a największy naturalny ubytek ludności charakteryzuje miasta: Krynicę-Zdrój (-4,3\%), Zakopane (-2,7\%o) i Ustroń (-2,2\%o) oraz gminę Rajczę (-3,2\%o).

Pod względem gospodarczym gminy, na terenie których leżą największe stacje narciarskie polskiej części Karpat, również są znacznie zróżnicowane. Przejawia się to m.in. w poziomie bezrobocia, poziomie przedsiębiorczości oraz w liczbie i strukturze podmiotów gospodarczych.

W 2004 r. największy udział zarejestrowanych bezrobotnych w liczbie ludności w wieku produkcyjnym notowano w gminach: Piwniczna-Zdrój (19,7\%), Ustrzyki Dolne (17,8\%), Rajcza (14,3\%) i Krynica-Zdrój (13,7\%), a najmniejszy w gminach: Bukowina Tatrzańska (6,2\%), Ustroń (7,8\%), Jeleśnia (8,0\%) i Poronin (8,6\%) (ryc. 2). W tym czasie wartość tego współczynnika dla Polski wynosiła 12,4\%, co oznacza, że w 12 badanych gminach poziom bezrobocia był niższy w stosunku do średniej dla naszego kraju. Z kolei w 2014 r. największymi wartościami omawianego wskaźnika cechowały się gminy: Ustrzyki Dolne (12,6\%), Rajcza (10,1\%), Zakopane $(9,9 \%)$ i Czorsztyn (9,7\%), a najmniejszymi - Ustroń (5,6\%), Brenna (5,8\%), Bukowina Tatrzańska (5,9\%) i Zawoja (6,4\%). W 2014 r. udział zarejestrowanych bezrobotnych w liczbie ludności w wieku produkcyjnym w Polsce wynosił 7,5\%. Niższą wartość tego współczynnika zanotowano w 7 badanych gminach.

Ryc. 2. Udział bezrobotnych zarejestrowanych w liczbie ludności w wieku produkcyjnym w $2004 \mathrm{r}$. i 2014 r. w gminach, na terenie których leżą badane stacje narciarskie

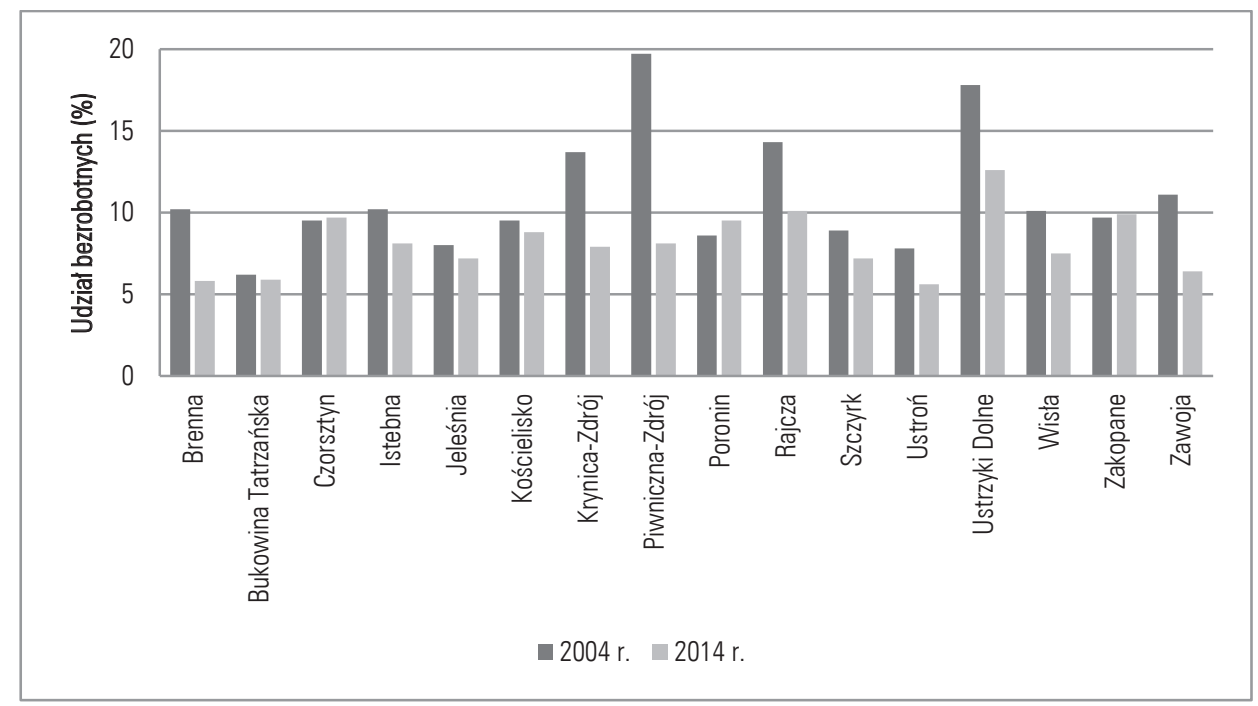

Źródło: opracowanie własne na podstawie danych z Banku Danych Lokalnych GUS (2014) 
Tab. 4. Sytuacja gospodarcza w gminach, na terenie których leżą badane stacje narciarskie, w latach 2004 i 2014

\begin{tabular}{|c|c|c|c|c|c|c|c|c|}
\hline \multirow[b]{3}{*}{ Gmina } & \multicolumn{5}{|c|}{ Podmioty gospodarki narodowej } & \multicolumn{3}{|c|}{ Przedsiębiorczość ${ }^{* *}$} \\
\hline & \multicolumn{2}{|c|}{2004} & \multicolumn{3}{|c|}{2014} & \multirow[b]{2}{*}{2004} & \multirow[b]{2}{*}{2014} & \multirow[b]{2}{*}{$\begin{array}{c}\text { zmiana } \\
\text { w latach } \\
\text { 2004-2014 } \\
{[\%]}\end{array}$} \\
\hline & ogółem & $\begin{array}{c}\text { w tym } \\
\text { prywatne }\end{array}$ & ogółem & $\begin{array}{c}\text { w tym } \\
\text { prywatne }\end{array}$ & $\begin{array}{c}\text { sekcja } H \\
\text { dzial } 49 \\
\text { i sekcja } \\
I^{*}\end{array}$ & & & \\
\hline Brenna & 959 & 944 & 1124 & 1108 & 160 & 94 & 102 & 8,5 \\
\hline $\begin{array}{l}\text { Bukowina } \\
\text { Tatrzańska }\end{array}$ & 847 & 825 & 1246 & 1220 & 566 & 69 & 95 & 37,7 \\
\hline Czorsztyn & 671 & 656 & 640 & 619 & 85 & 94 & 85 & $-9,6$ \\
\hline Istebna & 730 & 705 & 965 & 940 & 122 & 65 & 81 & 24,6 \\
\hline Jeleśnia & 946 & 904 & 1180 & 1139 & 158 & 70 & 88 & 25,7 \\
\hline Kościelisko & 696 & 672 & 961 & 938 & 288 & 87 & 111 & 27,6 \\
\hline Krynica-Zdrój & 1651 & 1611 & 2055 & 2010 & 363 & 98 & 122 & 24,5 \\
\hline Piwniczna-Zdrój & 702 & 677 & 913 & 890 & 115 & 68 & 86 & 26,5 \\
\hline Poronin & 945 & 925 & 1303 & 1278 & 488 & 89 & 114 & 28,1 \\
\hline Rajcza & 602 & 576 & 662 & 636 & 98 & 66 & 73 & 10,6 \\
\hline Szczyrk & 816 & 800 & 978 & 963 & 263 & 140 & 169 & 20,7 \\
\hline Ustroń & 2277 & 2224 & 2439 & 2392 & 351 & 148 & 152 & 2,7 \\
\hline Ustrzyki Dolne & 1544 & 1474 & 1633 & 1558 & 197 & 87 & 93 & 6,9 \\
\hline Wisła & 1591 & 1557 & 1732 & 1697 & 435 & 139 & 155 & 11,5 \\
\hline Zakopane & 5182 & 5063 & 5752 & 5648 & 1837 & 187 & 209 & 11,8 \\
\hline Zawoja & 758 & 731 & 806 & 777 & 123 & 86 & 89 & 3,5 \\
\hline
\end{tabular}

* Sekcja H dział 49 - Transport lądowy i rurociągowy, w tym obsługa wyciągów narciarskich, sekcja I - działalność związana z zakwaterowaniem i usługami gastronomicznymi.

** Podmioty wpisane do rejestru REGON na 1000 mieszkańców.

Źródło: opracowanie własne na podstawie Banku Danych Lokalnych GUS (2014)

Na przestrzeni 10 lat spadek poziomu bezrobocia nastąpił w 13 z 16 badanych gmin (ryc. 2). Największe pozytywne zmiany pod tym względem zaszły w gminach: Piwniczna-Zdrój, Krynica-Zdrój, Ustrzyki Dolne i Zawoja. W tych gminach wartość tego współczynnika zmniejszyła się odpowiednio o: $11,6 \%, 5,8 \%, 5,2 \%$ i 4,7\%. Niewielki wzrost poziomu bezrobocia zanotowano w gminach: Poronin (o 0,9\%), Czorsztyn (o 0,2\%) i Zakopane (o 0,2\%).

Według danych GUS w 2004 na terenie badanych gmin istniało łącznie 20,9 tys. podmiotów gospodarki narodowej, z których 97,3\% stanowiły podmioty należące do osób prywatnych (tab. 4). W 2014 r. liczba tych podmiotów wzrosła do 24,4 tys., a udział podmiotów prywatnych wzrósł do 97,6\%. Na przestrzeni 10 lat nastąpił więc wzrost liczby podmiotów gospodarki narodowej na badanym obszarze o 16,6\%. Najwięcej podmiotów zarejestrowanych było w Zakopanem, Ustroniu i gminie Krynica-Zdrój. W 2014 r. ich liczba wynosiła odpowiednio 5,7 tys., 2,4 tys. i 2,1 tys. Z kolei najmniej takich podmiotów działało na terenie gmin: Czorsztyn (0,6 tys.), Rajcza (0,7 tys.) i Zawoja (0,8 tys.). Podmioty działające w sekcji H dział 49, obejmującej m.in. działalność związaną z obsługą wyciągów narciarskich i sekcji I sklasyfikowanej jako działalność związana z zakwaterowaniem i usługami gastronomicznymi, stanowią 23,2\% 
ogółu jednostek zarejestrowanych w systemie REGON. Największym udziałem podmiotów z tych sekcji odznaczają się gminy podhalańskie: Bukowina Tatrzańska (45,4\%), Poronin (37,5\%), Zakopane (31,9\%) i Kościelisko (30,0\%), najmniejszym zaś: Ustrzyki Dolne (12,1\%), Istebna (12,6\%), Piwniczna-Zdrój (12,6\%), Czorsztn (13,3\%) i Jeleśnia (13,4\%).

Duże dysproporcje pomiędzy badanymi gminami są widoczne także w poziomie przedsiębiorczości lokalnej, mierzonej liczbą podmiotów gospodarczych na 1000 mieszkańców (tab. 4). Pod tym względem w 2014 r. najlepiej rozwinięte były gminy miejskie: Zakopane (209 podmiotów gospodarczych na 1000 mieszkańców), Szczyrk (169), Wisła (155) i Ustroń (152). Najniższe wskaźniki przedsiębiorczości cechowały natomiast gminy o charakterze wiejskim: Rajczę (73), Istebną (81) i Czorsztyn (85). W latach 2004-2014 wartość tego współczynnika wzrosła w Polsce średnio o 13,8\%. Natomiast w 7 z badanych gmin poziom przedsiębiorczości lokalnej wzrósł o co najmniej 25\%. Największy procentowy wzrost liczby podmiotów gospodarczych na 1000 mieszkańców nastąpił w gminach położonych na Podhalu, tj. w gminach: Bukowina Tatrzańska (wzrost o 37,7\%), Poronin (28,1\%) i Kościelisko $(27,6 \%)$, a także w gminach Piwniczna-Zdrój (26,5\%) i Jeleśnia (25,7\%) (tab. 4). Tylko w jednej z badanych gmin gminie Czorsztyn - wartość tego wskaźnika w ciągu 10 lat zmniejszyła się.

\section{Wnioski}

Przeprowadzone badania i analizy pozwalają na sformułowanie następujących wniosków:

1. Z punktu widzenia warunków społecznych i gospodarczych badane gminy są znacznie zróżnicowane. W zdecydowanie najkorzystniejszej sytuacji znajdują się te gminy, które cechują się wysokim poziomem rozwoju funkcji turystycznej, położone w Beskidzie Śląskim i na Podhalu. Charakteryzują się one przeważnie dodatnim saldem migracji, niższym od średniego dla Polski poziomem bezrobocia, wyższym od średniego poziomem przedsiębiorczości i wysokim udziałem podmiotów zajmujących się obsługą wyciągów narciarskich i kolei linowych, zakwaterowaniem i usługami gastronomicznymi. Odwrotne cechy wykazują natomiast gminy leżące w Beskidzie Żywieckim, Pieninach, Beskidzie Sądeckim i Bieszczadach.

2. W latach 2004-2014 najbardziej pozytywne zmiany w sytuacji społeczno-gospodarczej zaszły w gminach, w których w ostatnim piętnastoleciu nastąpił największy rozwój infrastruktury narciarskiej, tj. przede wszystkim w tych położonych $\mathrm{w}$ regionie podhalańskim i Beskidzie Sądeckim. Gminy te charakteryzują się największym rozwojem przedsiębiorczości lokalnej, wzrostem liczby ludności (Podhale) i spadkiem poziomu bezrobocia (Beskid Sądecki). Zdecydowanie wybijającą się pod względem korzystnych zmian w warunkach społecznych i gospodarczych jest gmina Bukowina Tatrzańska, na terenie której leżą 4 dynamicznie rozwijające się nowe stacje narciarskie. Miejscowości te są ośrodkami turystycznymi wyspecjalizowanymi w turystyce narciarskiej, która odgrywa dominującą rolę w strukturze ich funkcji turystycznej.

3. Mając na uwadze zachodzące od początku XXI w. zmiany w rozwoju ilościowym i jakościowym bazy dla narciarstwa zjazdowego w polskich Karpatach, można przewidywać, że wpływ turystyki narciarskiej na sytuację społeczno-gospodarczą gmin górskich będzie nadal wzrastać. Niewątpliwie zwiększać się będzie jej ekonomiczna siła oddziaływania na pozostałe działy sektora turystycznego, w szczególności na bazę noclegową, gastronomiczną i towarzyszącą, a także na inne usługi i budownictwo. 


\section{Literatura}

\section{References}

Bank Danych Lokalnych. GUS. (2015, 10 września). Pozyskano z www.stat.gov.pl

Barabasz, S. (1914). Wspomnienia narciarza. Zakopane: SN TT.

Baran, M. (2010). Koleje linowe i wyciąi narciarskie. Historia i dzień dzisiejszy. Łódź: Księży Młyn Dom Wydawniczy.

Barbier, B. (1978). Ski et stations de sports d'hiver dans le monde. Weiner Geographische Schriften, 51(52), 130-146.

Barbier, B. (1993). Problems of the French winter sport resort. Tourism Recreation Research, 18(2), 5-11.

Buckley, R.C., Pickering, C.M., Warnker, J. (2000). Environmental management for Alpine tourism and resorts in Australia. W: P.M. Goode, M.P. Price, F.M. Zimmermann (red.), Tourism and Development in Mountain Regions. Wallingford: CAB International, 27-45.

Christopoulou, O., Papastavrou, A. (1997). Evaluation of the behavior of visitors of ski stations for more effective management - the case of the Pelion region. Medit, 8(1), 37-40.

Čuka, P., Gregorová, B. (2011). Cechy i kierunki urbanizacji turystycznej na Słowacji - przykład stacji narciarskiej Donovaly. Prace Geograficzne, 125, 9-18.

Greif, F. (1988). Landwirtschaft. Forstwirtschaft und Wintersport - Zum Konflikt zwischen Ökologie und Ökonomie in Österreichs Bergen. W: Probleme des ländlichen Raumes im Hochgebirge. Innsbrucker Geographische Studien, 16.

Havrlant, J. (2011). Kierunki i bariery modernizacji ośrodków sportów zimowych w czeskim regionie turystycznym „Beskidy”. Prace Geograficzne, 125, 77-93.

Knafau, R. (1979). L'aménagement de territoire en économie libérale: l'example des stations intégrées de sports d'hiver des Alpes Françaises. l'Espace Géographique, 83, 173-180.

Krzesiwo, K. (2014). Rozwój i funkcjonowanie stacji narciarskich w polskich Karpatach, Kraków: Instytut Geografii i Gospodarki Przestrzennej UJ.

Kurek, W. (2004). Turystyka na obszarach górskich Europy, Kraków: Instytut Geografii i Gospodarki Przestrzennej UJ.

Lasanta, T., Laguna, M., Vicente-Serrano, S. M. (2007). Do tourism-based ski resorts contribute to the homogeneous development of the Mediterranean mountains? A case study in the Central Spanish Pyrenees. Tourism Management, 28, 1326-1339.

Lindberg, K., Andersson, T.D., Dellaert, B.G.C. (2001). Tourism development: Assessing social gains and losses. Annals of Tourism Research, 28(4), 1010-1030.

Mika, M. (2004). Turystyka a przemiany środowiska przyrodniczego Beskidu Śląskiego. Kraków: Instytut Geografii i Gospodarki Przestrzennej UJ.

Mika, M. (2014). Założenia i determinanty podtrzymywalności lokalnego rozwoju turystyki. Kraków: Instytut Geografii i Gospodarki Przestrzennej UJ.

Orens, A., Seidl, A., Weiler, S. (2006). Winter Tourism and Land Development in Gunnison, Colorado. W: T. Clark, A. Gill, R. Hartmann (red.), Mountain Resort Planning and Development in the Era of Globalization. New York: Cognizant Communication Corporation, 91-107.

Paryski, W.H., Paryska, Z. (1994). Wielka encyklopedia tatrzańska, Poronin.

Snowdon, P., Slee, B., Farr, H. (2000). The Economic impacts of Different Types of Tourism in Upland and Mountain Areas of Europe. W: P. M. Goode, M. F. Price, F. M. Zimmermann (red.), Tourism and Development in Mountain Regions. Wallingford: CAB International, 137-155.

Szatkowski, W. (1994). Pionierzy narciarstwa w Tatrach Polskich. Zakopane: Muzeum Tatrzańskie im. T. Chałubińskiego.

Szatkowski, W. (2011). Stanisław Barabasz - pierwszy zakopiański narciarz. Pozyskano z (www.watra.pl/ zakopane/gory/2011/02/03/stanislaw-barabasz-pierwszy-zakopianski-narciarz).

Ziemba, S. (1957). Zanim przyszły czasy Legierskich, Wieczorka i Tajnera. W: Na śnieżnych trasach Beskidów. Katowice: Wyd. Sekcji Narciarskiej WKKF Katowice, 7-15. 
Zimmermann, F.M. (1995). The Alpine Region: Regional Restructuring Opportunities and Constraints in a Fragile Environment. W: A. Montanari, A. M. Williams (red.), European Tourism: Regions, Spaces and Restructuring. Chichester - New York: Wiley, 19-40.

Kinga Krzesiwo, dr, Uniwersytet Pedagogiczny im. Komisji Edukacji Narodowej w Krakowie, Instytut Geografii, Zakład Przedsiębiorczości i Gospodarki Przestrzennej. Zainteresowania badawcze autorki dotyczą rozwoju i funkcjonowania ośrodków i stacji narciarskich w Polsce oraz na świecie, atrakcyjności i konkurencyjności turystycznej, nowych trendów rozwoju turystyki, a także metodologii badań w geografii turyzmu. Ponadto autorka zajmuje się prowadzeniem badań marketingowych oraz badań ruchu turystycznego w wybranych górskich miejscowościach turystycznych.

Kinga Krzesiwo, PhD, Pedagogical University of Cracow, Institute of Geography, Department of Entrepreneurship and Spatial Management. Her research interests focus primarily on the issue of development and functioning of ski resorts in Poland and in the world, tourist attractiveness and tourist competitiveness, new trends in tourism development as well as research methodology in geography of tourism. Furthermore, the author carries out the marketing research and the research of tourist traffic in the selected mountain localities.

\section{Adres/Address:}

Uniwersytet Pedagogiczny im. Komisji Edukacji Narodowej w Krakowie

Instytut Geografii

Zakład Przedsiębiorczości i Gospodarki Przestrzennej

ul. Podchorążych 2

30-084 Kraków, Polska

e-mail: kingakrz@interia.pl 